\title{
THE IMPACT OF THE COMPREHENSIVE TREATMENT OF THE PNEUMOCONIOSIS COMBINED WITH THE CHRONIC OBSTRUCTIVE PULMONARY DISEASE ON SOME INTOXICATION INDICATORS IN ORE MINING AND IRON AND SIEEL INDUSTRY WORKERS
}

Rubtsov R.V.

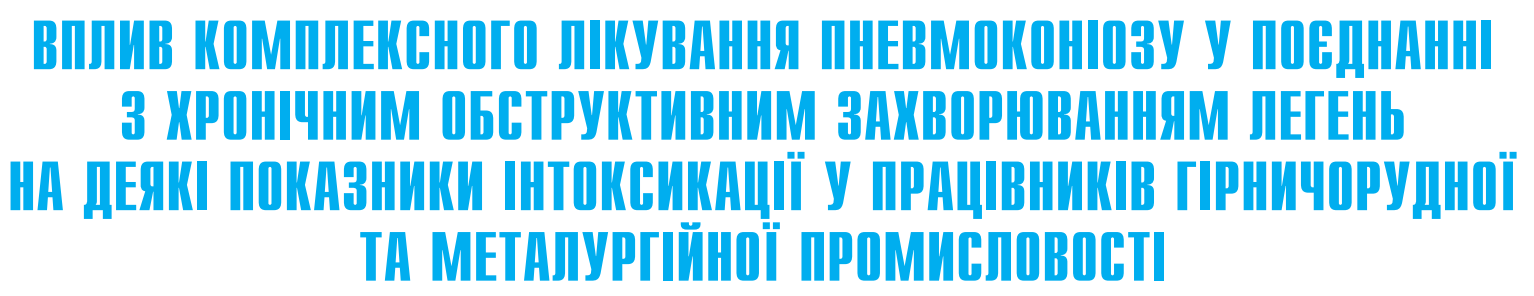

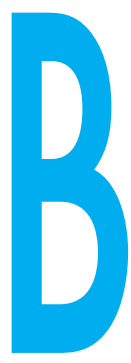

РУБцОВ Р.в.

ДУ «Український науково-дослідний інститут промислової медицини», м. Кривий Ріг умовах сучасного промислового виробництва провідним несприятливим фактором $€$ пиловий. Нині «пилова» патологія легень $є$ тією групою захворювань, що посідає чільне місце у структурі професійних захворювань [1]. У працівників гірничорудної та металургійної промисловості найбільш поширеними нозологічними формами професійних захворювань $є$ пневмоконіоз (ПК) та хронічне обструктивне захворювання легень (ХОЗЛ) професійної етіології. Саме ці хвороби $€$ одними з головних чинників, які зумовлюють суттєві економічні та соціальні втрати, вражаючи робітників працездатного віку [2, 3].

Актуальними напрямками у лікуванні ХОЗЛ та ПК є заходи, які регламентуються сучасними міжнародними та вітчизняними протоколами та рекомендаціями. Так, ліку- вання ХОЗЛ ґрунтується на застосуванні препаратів бронхолітичної дії, до яких належать М-холінолітики та 2-агоністи. Їхня дія спрямована на досягнення контролю захворювання та модифікацію його перебігу. Комбінація цих лікарських засобів тривалої дії, а також глюкокортикостероїдів у вигляді дозованих аерозолів дозволяє діяти безпосередньо на «locus morbi», уникаючи системних ускладнень, що виникають внаслідок тривалого їх застосування. Окрім того, додатково застосовуються засоби для покращання відходження мокротиння, зменшення активності запалення, підвищення загальної резистентності організму хворого [4-7].

3 іншого боку, лікування ПК у більшості випадків є симптоматичним, тобто спрямованим на усунення усклад-
ВПЛИВ КОМПЛЕКСНОГО ЛІКУВАННЯ

ПНЕВМОКОНІОЗУ У ПОЕДНАННІ

3 ХРОНІЧНИМ ОБСТРУКТИВНИМ

ЗАХВОРЮВАННЯМ ЛЕГЕНЬ НА ДЕЯКІ

ПОКАЗНИКИ ІНТОКСИКАЦІЇ У ПРАЦІВНИКІВ

ГІРНИЧОРУДНОЇ ТА МЕТАЛУРГІЙНОІ

ПРОМИСЛОВОСТІ

Рубцов Р.В.

ДУ «Український науково-дослідний інститут промислової медицини», м. Кривий Ріг

Мета дослідження. Вивчити ефективність комплексного лікування працівників гірничорудної та металургійної промисловості, хворих на пневмоконіоз у поєднанні з хронічним обструктивним захворюванням легень, за показниками інтоксикації для оцінки заходів з лікування та профілактики цієї професійної патології легень.
Результати. Встановлено, що проведене лікування з застосуванням бронхолітика, мукорегулятора, засобу протизапальної дії, комплексного вітамінного препарату, а також сеансів гіпербаричної оксигенації за Ата 1,3 атмосфери у хворих працівників гірничорудної та металургійної промисловості дозволило знизити активність процесів запалення за вмістом у периферичній крови загальної кількості лейкоцитів, їхніх паличкоядерних та сегментоядерних субпопуляцій, зменшити більшість індексів інтоксикації: лейкоцитарний індекс інтоксикації, гранулоцитарно-агранулоцитарний індекс, загальний індекс інтоксикації, індекс зсуву ліворуч та індекс співвідношення лейкоцитів та швидкості осідання еритроцитів, вказуючи на зниження активності системного запалення з одночасним

С Рубцов Р.В. СТАТТЯ, 2020. 
нень, які виникають під час захворювання [1].

Оцінка ефективності лікування ХОЗЛ ґрунтується на різних рівнях. Насамперед, за показниками клінічних проявів, функціонального стану легень та кількості загострень хвороби. Безперечно, зважаючи на оцінку ХОЗЛ як системного запалення 3 переважним ураженням слизової оболонки бронхів, оцінка ефективності лікування цього захворювання є більш об'єктивною з урахуванням активності запалення та вираженості процесів інтоксикації на системному та місцевому рівнях [ 8-11].

Поєднаний перебіг ПК та ХОЗЛ у працівників гірничорудної та металургійної промисловості потребує впровадження системних підходів до лікування, які дають змогу сфокусувати зусилля на усуненні основних патогенетичних механізмів цього професійного захворювання. Введення до комплексу лікування ПК у поєднанні з ХОЗЛ засобів, дія яких спрямована на дилатацію бронхів, протизапальну дію, покращання реактивності організму та гіперосмії, $€$ підґрунтям для покращання перебігу хвороби та якості життя хворих працівників. Застосування цих методів лікування $€$ визначальним у формуванні саногенетичного підґрунтя

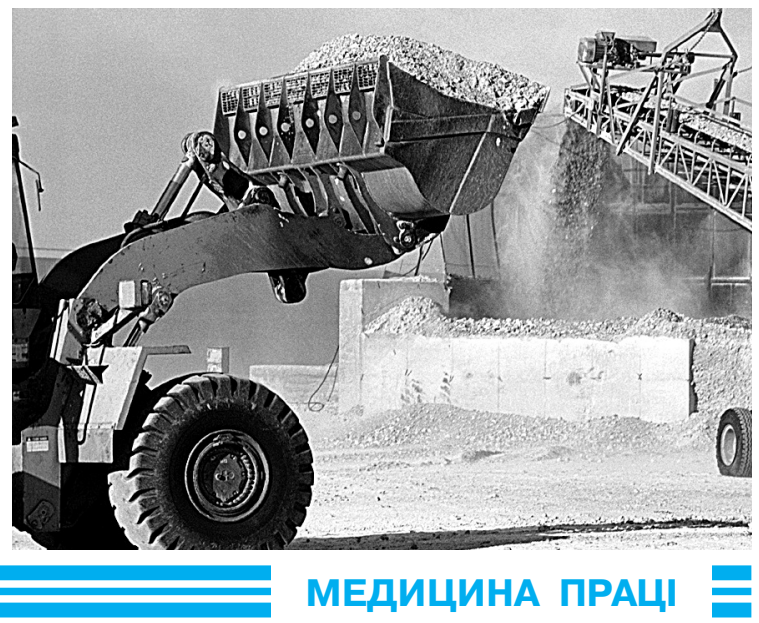

для покращання клінічної симптоматики та функціонального стану органів дихання, визначаючи актуальність проведених досліджень.

Мета дослідження. Вивчити ефективність комплексного лікування працівників гірничорудної та металургійної промисловості, хворих на ПК у поєднанні 3 ХОЗЛ, за показниками інтоксикації для оцінки заходів з лікування та профілактики цієї професійної патології легень.

Об'єкт і методи дослідження. На підставі отриманих у результаті проведених у клініці ДУ «УКРНДІПРОММЕД» у 2012-2015 роки досліджень особливостей клінічних проявів та функціонального стану органів дихання було розроблено та апробовано методику патогенетично обґрунтованого лікування та профілактики ПК у поєднанні з ХОЗЛ у працівників гірничорудної та мета- лургійної промисловості. Сутністю комплексного лікування $€$ застосовування сучасних методів усунення обструкції бронхів, зменшення активності системних процесів інтоксикації, покращання експекторації мокротиння та усунення явищ гіпоксії призначенням протягом 14 діб сальбутамолу 2,5 мг шляхом вдихання через рот за допомогою небулайзера двічі на добу; флютиказону пропіонату 1 мг шляхом вдихання через рот за допомогою небулайзера двічі на добу; вдихання амброксолу гідрохлориду 7,5-15 мг через рот за допомогою небулайзера двічі на добу; комплексного вітамінного препарату, який містить: 50 мг піридоксину гідрохлориду, 50 мг тіаміну гідрохлориду, 0,5 мг допоміжної речовини: лідокаїну гідрохлориду, калію гексаціаноферату, натрію поліфосфату, натрію гідрохлориду, спирту бензилового, води пригніченням явищ інтоксикації. Порівняно з іншими хворими з професійними захворюваннями легень комплексне лікування зумовило більш вагоме зменшення вмісту сегментоядерних та паличкоядерних лейкоцитів, а також основних інтегральних індексів інтоксикації: лейкоцитарний індекс інтоксикації, гранулоцитарно-агранулоцитарний індекс, загальний індекс інтоксикації. Таким чином, комплексне лікування працівників гірничорудної та металургійної промисловості, хворих на пневмоконіоз у поєднанні з хронічним обструктивним захворюванням легень, $\epsilon$ важливою ланкою у системі заходів з лікування та профілактики цієї професійної патології легень.

Висновки. У працівників гірничорудної та металургійної промисловості, хворих на пневмоконіоз у поєднанні з хронічним обструктивним захворюванням легень, комплексне лікування з застосуванням бронходилятатора, протизапального засобу, мукорегулятора за допомогою небулайзера, комплексного вітамінного препарату групи В внутрішньом'язово та гіпербаричної оксигенації дозволило покращити деякі показники запалення та індексів інтоксикації, що є предиктором позитивного перебігу захворювання. Оцінка результатів проведеного комплексного лікування хворих працівників вказує на суттєву позитивну динаміку процесів інтоксикації та дозволяє розглядати його як важливу ланку у системі заходів, спрямованих на лікування та профілактику цього професійного захворювання легень.

Ключові слова: пневмоконіоз, хронічне обструктивне захворювання легень, працівники, інтоксикація. 
для ін'єкцій внутрішньом'язово один раз на добу; сеансів гіпербаричної оксиАта 1,3 атмосфери. Основну групу сформовано з 25 осіб, яким було застосовано комплексне лікування ПК у поєднанні з ХОЗЛ. Групу порівняння склали 29 працівників 3 ПК у поєднанні з ХОЗЛ, яким було проведено курс традиційного лікування 3 застосуванням бронхолітика короткої дії сальбутамолу 100 мкг (2 дози 4 рази на добу), мукорегулятора амброксолу гідрохлориду 30 мг тричі на добу та вітамінів групи В (50 мг піридоксину гідрохлориду, 50 мг тіаміну гідрохлориду) по 1 мл внутрішньом'язово протягом 15 діб. Середній вік працівників склав $(58,6 \pm 2,4)$ років, стаж роботи у несприятливих умовах - $(18,9 \pm 0,8)$ років.

Ефективність методу лікування оцінювалася (до та після лікування) за лабораторними показниками. Після забору крови із пальця визначали вміст еритроцитів в 1 літрі крови у камері Горяєва (у 1012 г/л), показник гемоглобіну - гемоглобінціанідним методом (г/л), кольоровий генації протягом 60 хвилин за

показник (співвідношення гемоглобіну та подвійної першої цифри кількості еритроцитів в 1 мкл). Абсолютний вміст лейкоцитів в одному мілілітрі крови визначався за методом візуального підрахунку у 1600 дрібних квадратах камери Горяєва з локальним збільшенням мікроскопа у затемненому полі зору за загально визначеною методикою. Кількість лейкоцитів розраховувалася за формулою:

ЛЦ = A $\times 4000 \times 20 / 1600$, (1) де ЛЦ - кількість лейкоцитів в 1 мл крови;

А - кількість підрахованих лейкоцитів у 1600 квадратах; 20 - розведення крови;

4000 - коефіцієнт, який переводить результат до об'єму 1 мл крови.

Підрахунок лейкоцитарної формули здійснювався у забарвлених за РомановськимГімзе мазках під імерсією (об'єктив мікроскопа 100, окуляр 10). Підраховували 200 лейкоцитів на зигзагоподібній лінії «Мендра» таким чином: 3-5 ділянок зору по краю мазка, потім 3-5 ділянок зору під прямим кутом до середини мазка, потім 3-5 ділянок зору паралельно

Таблиця 1

Ефективність лікування пневмоконіозу у поєднанні з ХОЗЛ у працівників гірничорудної промисловості за показниками загальноклінічного аналізу крови

\begin{tabular}{|l|c|c|c|c|}
\hline \multirow{2}{*}{\multicolumn{1}{|c|}{ Показники }} & \multicolumn{2}{|c|}{ Основна група (п=25) } & \multicolumn{2}{|c|}{ Група порівняння (п=29) } \\
\cline { 2 - 5 } & $\begin{array}{c}\text { До } \\
\text { лікування }\end{array}$ & $\begin{array}{c}\text { Після } \\
\text { лікування }\end{array}$ & $\begin{array}{c}\text { До } \\
\text { лікування }\end{array}$ & $\begin{array}{c}\text { Після } \\
\text { лікування }\end{array}$ \\
\hline Еритроцити & $4,7 \pm 0,6$ & $4,7 \pm 0,6$ & $4,7 \pm 0,1$ & $4,7 \pm 0,05$ \\
\hline Гемоглобін & $148,2 \pm 2,2$ & $147,4 \pm 2,5$ & $150,3 \pm 2,1$ & $147,9 \pm 2,2$ \\
\hline шОЕ & $11,4 \pm 1,5$ & $11,0 \pm 1,6$ & $10,6 \pm 1,5$ & $10,4 \pm 1,3$ \\
\hline Лейкоцити & $8,9 \pm 2,2$ & $6,0 \pm 0,3$ & $5,7 \pm 0,3$ & $5,7 \pm 0,3$ \\
\hline Сегментоядерні & $59,0 \pm 1,8$ & $56,6 \pm 1,6$ & $54,7 \pm 2,3$ & $57,2 \pm 2,5$ \\
\hline Паличкоядерні & $4,3 \pm 0,8$ & $3,6 \pm 0,6$ & $5,6 \pm 1,7$ & $5,5 \pm 1,8$ \\
\hline Моноцити & $7,0 \pm 0,7$ & $7,6 \pm 0,7$ & $7,0 \pm 0,9$ & $7,6 \pm 0,6$ \\
\hline Лімфоцити & $27,0 \pm 1,9$ & $27,6 \pm 1,5$ & $28,5 \pm 1,8$ & $27,2 \pm 1,9$ \\
\hline Еозинофіли & $2,3 \pm 0,4$ & $3,4 \pm 0,5$ & $3,8 \pm 1,3$ & $2,9 \pm 0,6$ \\
\hline
\end{tabular}

Примітки до таблиць 1 і 2:

* - різниця достовірна порівняно з показниками до лікування $(p<0,05)$;

** - різниця достовірна порівняно з показниками після лікування в основній групі $(p<0,05)$. краю та знову під прямим кутом. Такий саме рух до підрахунку 200 клітин. Розраховували процентний вміст різних субпопуляцій лейкоцитів: паличкоядерних (П), сегментоядерних (C), нейтрофілів $(\mathrm{H})$, еозинофілів $(\mathrm{E})$, моноцитів (МЦ), лімфоцитів (Л). За допомогою капіляра Панченкова визначали швидкість осідання еритроцитів (ШОЕ) крови у суміші 3 цитратом натрію у співвідношенні 1/4, яку оцінювали у міліметрах за годину.

Лейкоцитарні індекси інтоксикації розраховували за такими формулами:

1. Лейкоцитарний індекс інтоксикації - (ЛІІ)

$ת I I=(4 M+3 Ю+2 П+C) \times \Pi л+1)$ $(М Ц+Л) \times(E+1)$,

у нормі - до 1,5.

2. Гранулоцитарно-агранулоцитарний індекс (ГАІ)

$\Gamma A I=C+\Pi+E+Б / M Ц+Л$,

у нормі - $(1,96 \pm 0,56)$.

3. Індекс зсуву ліворуч (ICB)

$I C B=\Pi \times 100 / C$,

у нормі -до 6,9.

4. Загальний індекс інток-

сикації (ЗІІ)

$3 \| I=Л I I+\Gamma A I+I C B$,

у нормі - 10,3.

5. Індекс співвідношення лейкоцитів та ШОЕ (ICШOE)

ICШOE = Л $\times$ ШOE/100, у нормі - $(0.3 \pm 2,5)$

6. Лімфоцитарно-гранулоцитарний індекс (ІЛГ) ІЛГ=Лx10/M+MT+П+E+Б+C, (7) у нормі - 3-5.

7. Сума ІЛСОЕ та

ІЛГ=ІЛСОЕ+ІЛГ,

у нормі - 3,3-7,9.

Діагноз ПК було встановлено відповідно до рентгенологічної класифікації Міжнародної Організації Праці (МОП) 1980 року. Діагноз ХОЗЛ було встановлено на підставі Міжнародних критеріїв GOLD, а також Наказу МОЗ України від 27.06 .2013 р. № 555 «Про затвердження та впровадження медико-технологічних документів зі стандартизації медичної допомоги при хронічному обструктивному захворюванні легень» [3, 12, 13].

Усі працівники надали письмову згоду на проведення 
THE IMPACT OF THE COMPREHENSIVE TREATMENT OF THE PNEUMOCONIOSIS COMBINED WITH THE CHRONIC

OBSTRUCTIVE PULMONARY DISEASE ON SOME INTOXICATION INDICATORS IN ORE MINING AND IRON AND STEEL INDUSTRY WORKERS

Rubtsov R.V.

State Institution «Ukrainian Research Institute of Industrial Medicine», Kryvyi Rih, Ukraine

Objective: We studied the efficiency of the comprehensive treatment of ore mining and iron and steel industry workers having the pneumoconiosis combined with chronic obstructive pulmonary disease in terms of intoxication indicators as an assessment of measures aimed at treatment and prevention of this occupational pulmonary pathology. Results: It was established that conducted treatment in the patients, ore mining and iron and steel industry workers with the use of bronchodilator, mucoregulator, anti-inflammatory agent of a complex vitamin medication, as well as sessions of hyperbaric oxygenation at $1.3 \mathrm{~atm}$ led to a decrease in the activity of inflammation processes with regard to the content in the peripheral blood of the total number of leukocytes, their stab and segmented subpopulations, and a decrease in most intoxication indices: the leukocytic index of intoxication, the granulocytic-agranulocytic index, the general index of intoxication, the sinistroposition index, the index of the ratio of leukocytes to erythrocyte sedimentation rate, which indicates a decrease in the systemic inflammation activity with the simultaneous suppression of intoxication phenom- ena. In comparison with the patients with other occupational lung pathology, the comprehensive treatment led to a more significant decrease in the content of segmented and stab leukocytes, as well as the main integral intoxication indices: the leukocytic index of intoxication, the granulocytic-agranulocytic index, and the general index. Thus, the comprehensive treatment of ore mining and iron and steel industry workers having the pneumoconiosis combined with the chronic obstructive pulmonary disease is an important link in the system of measures aimed at treatment and prevention ofthis occupational pulmonary pathology.

Conclusions: In the ore mining and iron and steel industry workers having the pneumoconiosis combined with the chronic obstructive pulmonary disease, the comprehensive treatment with the use of bronchodilator, mucoregulator, nebulizer-administered anti-inflammatory agent, a complex vitamin B medication administered intramuscularly, as well as sessions of hyperbaric oxygenation led to an improvement in some inflammation indicators and intoxication indices which is a predictor of a positive course of the disease. The assessment of the results of the conducted comprehensive treatment of the workers indicates a significant positive dynamics of intoxication processes and makes it possible to regard this treatment as an important link in the system of measures aimed at treatment and preventionofthisoccupational pulmonary disease.

\section{Keywords: pneumoconiosis, chronic obstructive pulmonary disease, workers, intoxication.}

дослідження відповідно до етичних принципів Гельсінської Декларації щодо участі людини як об'єкта дослідження та їх поінформованості, 3 дозволу комісії з біоетики ДУ «УКРНДІПРОММЕД» (протокол № 93 від 30.04.2015 р.).

Обробку матеріалу проводили з застосуванням стандартного пакета програм Microsoft Office Excel. Отримані дані мали нормальний закон розподілу ймовірностей, для їх аналізу використовувалися переважно параметричні критерії Ст'юдента і Фішера. Кількість спостережень була достатньою для отримання незміщених оцінок перших двох моментів: середньої арифметичної (М) та середньоквадратичного відхилення ( $\delta)$. Для порівнян- ня середніх величин кількісних показників за нормального розподілу ознаки використовували t-критерій Ст'юдента. Достовірним вважали рівень значущості $\mathrm{p} \leq 0,053$ надійністю 95\%.

Результати та їх обговорення. Загальноклінічні лабораторні показники загального аналізу крови (табл. 1) після проведеного комплексного лікування хворих на ПК у поєднанні з ХОЗЛ мали таку спрямованість: вміст еритроцитів, гемоглобіну, лімфоцитів та ШОЕ суттєво не змінилися. Було встановлено зменшення вмісту у крові лейкоцитів на 48,3\% та їхніх паличкоядерних субпопуляцій на 19,4\%. Водночас, проведене лікування зумовило збільшення вмісту моноцитів на 8,6\% та еозинофілів на $47,8 \%$.

у групі порівняння вміст еритроцитів, лейкоцитів, їхніх паличкоядерних субпопуляцій та показник ШОЕ після лікування також суттєво не змінилися. Збільшився вміст сегментоядерних лейкоцитів на 4,6\% та моноцитів на 8,6\%. Навпаки, зменшився вміст лімфоцитів на 4,7\%, еозинофілів на 31,0\% та гемоглобіну на 1,6\%. Після порівняння показників загального аналізу крови хворих основної групи та іншої після проведеного лікування було встановлено, що вміст паличкоядерних та сегментоядерних лейкоцитів у першій з них був меншим відповідно на $1,1 \%$ та $52,7 \%$, а їх загальна кількість, навпаки, була більшою

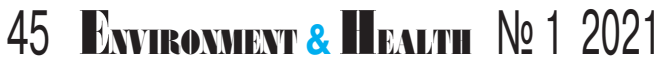


на $5,2 \%$. Вміст еозинофілів також був більшим на $17,2 \%$.

Наведені у таблиці 2 дані вказують на те, що комплексне лікування працівників, хворих на ПК у поєднанні з ХОЗЛ, зумовило зміну активності процесів інтоксикації. Значно зменшилися показники індексів інтоксикації: ЛІІ - на $25,0 \%$, ГАІ - на 10,0\%, 3ІІ - на $12,7 \%$, ІЛШОЕ також зменшився на $26,4 \%$. Навпаки, ІЛГ збільшився на 4,6\%. У групі порівняння після лікування зросла більшість індексів інтоксикації: ЛІІ - на 14,2\%, ГАІ - на $10,5 \%$, 3II - на 4,2\%. Деякі з них зменшилися: ІЛГ - на $11,9 \%$, ІЛШОЕ + ІЛГ - на $5,4 \%$.

Порівняння показників індексів інтоксикації у вказаних групах хворих працівників після проведеного лікування показало, що в основній групі деякі з них були меншими, ніж у хворих групи порівняння: ЛІІ - на 60,0\%, 3III - на 4,3\%, ГAI - на 5,0\%. Низка інших індексів була, навпаки, більшою: ІЛШОЕ - на $13,3 \%$, ІЛГ - на $7,1 \%$, ІЛШОЕ+ ІЛГ - на 1,4\%.

Отже, отримані результати досліджень вказують, що лікування 3 застосуванням бронхолітика, мукорегулятора, засобу протизапальної дії через небулайзер, комплексного вітамінного препарату, який вводився внутрішньом'язово, а також сеансів гіпербаричної оксигенації за Ата 1,3 атмосфери у праців- ників гірничорудної та металургійної промисловості, хворих на ПК у поєднанні 3 ХОЗЛ, зумовило зниження активності процесів запалення за вмістом у периферичній крови загальної кількості лейкоцитів, їхніх паличкоядерних та сегментоядерних субпопуляцій. Водночас, суттєво зменшилася кількість індексів інтоксикації: ЛII, ГАІ, 3II, ICЗ та ІЛШОЕ, що підтверджує зниження активності системного запалення 3 одночасним пригніченням явищ інтоксикації на тлі переважно інфекційного ураження легень хворих. Підтвердженням значущості отриманих результатів $€$ порівняння отриманих даних щодо лікування основної групи хворих працівників з групою порівняння, яким було застосовано традиційне лікування. Встановлено, що проведене комплексне лікування зумовило значне зменшення сегментоядерних та паличкоядерних лейкоцитів, а також схожу динаміку основних інтегральних індексів інтоксикації: ЛІІ, ЗІІІ та ГАІ. Отже, виявлене внаслідок проведеного комплексного лікування працівників гірничорудної та металургійної промисловості, хворих на ПК у поєднанні з ХОЗЛ, зменшення індексів інтоксикації є важливою ланкою у визначенні позитивного прогнозу перебігу цієї професійної патології легень.

Таблиця 2

Ефективність лікування пневмоконіозу у поєднанні з ХОЗЛ у працівників гірничорудної промисловості за показниками індексів інтоксикації ( \pm m)

\begin{tabular}{|l|c|c|c|c|}
\hline \multirow{2}{*}{ Показники } & \multicolumn{2}{|c|}{ Основна група (п=25) } & \multicolumn{2}{|c|}{ Група порівняння (п=29) } \\
\cline { 2 - 5 } & $\begin{array}{c}\text { До } \\
\text { лікування }\end{array}$ & $\begin{array}{c}\text { Після } \\
\text { лікування }\end{array}$ & $\begin{array}{c}\text { До } \\
\text { лікування }\end{array}$ & $\begin{array}{c}\text { Після } \\
\text { лікування }\end{array}$ \\
\hline ЛІІ & $0,4 \pm 0,1$ & $0,5 \pm 0,07$ & $0,7 \pm 0,1$ & $0,8 \pm 0,1$ \\
\hline ГАІ & $2,2 \pm 0,3$ & $2,0 \pm 0,1$ & $1,9 \pm 0,1$ & $2,1 \pm 0,1$ \\
\hline ІСВ & $7,8 \pm 1,4$ & $7,1 \pm 1,2$ & $6,9 \pm 1,1$ & $7,1 \pm 1,0$ \\
\hline ЗІІ & $10,6 \pm 1,5$ & $9,4 \pm 1,3$ & $9,4 \pm 1,2$ & $9,8 \pm 1,0$ \\
\hline ІЛ ШОЕ & $4,3 \pm 1,0$ & $3,4 \pm 0,6$ & $3,0 \pm 0,4$ & $3,0 \pm 0,6$ \\
\hline ІЛГ & $4,3 \pm 0,5$ & $4,5 \pm 0,3$ & $4,7 \pm 0,4$ & $4,2 \pm 0,3$ \\
\hline ІЛШОЕ+ІЛГ & $7,3 \pm 0,7$ & $7,4 \pm 0,9$ & $7,7 \pm 0,6$ & $7,3 \pm 0,8$ \\
\hline
\end{tabular}

\section{Висновки}

1. У працівників гірничорудної та металургійної промисловості, хворих на ПК у поєднанні з ХОЗЛ, комплексне лікування з застосуванням бронходилятатора, протизапального засобу, мукорегулятора за допомогою небулайзера, комплексного вітамінного препарату групи В внутрішньом'язово та гіпербаричної оксигенації зумовило покращання деяких показників запалення та основних інтегральних показників індексів інтоксикації, що є предиктором позитивного перебігу захворювання.

2. Оцінка результатів проведеного комплексного лікування працівників гірничорудної та металургійної промисловості, хворих на ПК у поєднанні з ХОЗЛ, вказує на суттєву позитивну динаміку процесів інтоксикації та дозволяє розглядати його як важливу ланку у системі комплексних заходів, спрямованих на лікування та профілактику цього професійного захворювання легень.

ЛІТЕРАТУРА

1. Шпагина Л.А., Потеряева Е.Л., Котова О.С., Шпагин И.С., Смирнова Е.Л. Актуальные проблемы пульмонологии в современной профпатологической практике. Медицина труда и промышленная экология. 2015. № 9. С. 11-14.

2. Елесевич С.А., Разумов В.В. О патогенетическом единстве пневмокониозов и пылевого бронхита.

Медицина труда и промышленная экология. 2007. № 7. C. 28-33.

3. Краснюк О.П., Ткач С.І., Прилипська Н.І., Шкондін А.М., Ковальчук Т.А., Валуцина В.М. Застосування класифікації пневмоконіозів в Україні: методичні рекомендації. К., 2002. 15 с.

4. Loh C.H., Donohue J.E., Ohar J.A., Review of drung safety and efficacy of arformoterol in chronic obstructive pulmonary disease. Expert. Opin. Drug Saf. 2015. Vol. 14 (3). P. 463-472. 
ВЛИЯНИЕ КОМПЛЕКСНОГО ЛЕЧЕНИЯ ПНЕВМОКОНИОЗА В СОЧЕТАНИИ С ХРОНИЧЕСКИМ ОБСТРУКТИВНЫМ ЗАБОЛЕВАНИЕМ ЛЕГКИХ НА НЕКОТОРЫЕ ПОКАЗАТЕЛИ ИНТОКСИКАЦИИ

У РАБОТНИКОВ ГОРНОРУДНОЙ

И МЕТАЛЛУРГИЧЕСКОЙ

ПРОМЫШЛЕННОСТИ

Рубцов Р.в.

ГУ «Украинский научно-исследовательский институт промышленной медицины», г. Кривой Рог, Украина

Цель исследования. Изучить эффективность комплексного лечения работников горнорудной и металлургической промышленности с пневмокониозом в сочетании с хроническим обструктивным заболеванием легких по показателям интоксикации в качестве оценки мероприятий, направленных на лечение и профилактику данной профессиональной патологии легких.

Результаты. Установлено, что проведенное лечение с использованием бронхолитика, мукорегулятора, средства с противовоспалительным действием, комплексного витаминного препарата, а также сеансов гипербарической оксигенации при Ата 1,3 атмосферы у пациентов, работников горнорудной и металлургической промышленности, привело к снижению активности процессов воспаления относительно содержания в периферической крови общего количества лейкоцитов, их палочкоядерных и сегментоядерных субпопуляций, к уменьшению большинства индексов интоксикации: лейкоцитарного индекса интоксикации, гранулоцитарно-агранулоцитарного индекса, общего индекса интоксикации, индекса смещения влево, индекса соотношения лейкоцитов и скорости оседания эритроцитов, указывая на снижение активности системного воспаления с одновременным угнетением явлений интоксикации. В сравнении с пациентами с другой профессиональной патологией легких комплексное лечение привело к более значимому снижению содержания сегментоядерных и палочкоядерных лейкоцитов, а также основных интегральных индексов интоксикации: лейкоцитарного индекса интоксикации, гранулоцитарноагранулоцитарного индекса, общего индекса. Таким образом, комплексное лечение работников горнорудной и металлургической промышленности с пневмокониозом в сочетании с хроническим обструктивным заболеванием легких является важным звеном в системе мероприятий, направленных на лечение и профилактику данной профессиональной патологии легких.

Выводы. У работников горнорудной и металлургической промышленности с пневмокониозом в сочетании с хроническим обструктивным заболеванием легких комплексное лечение с использованием бронхолитика, мукорегулятора, средства с противовоспалительным действием при помощи небулайзера, комплексного витаминного препарата группы В внутримышечно, а также сеансов гипербарической оксигенации привело к улучшению некоторых показателей воспаления и индексов интоксикации, что является предиктором позитивного течения болезни. Оценка результатов проведенного комплексного лечения работников указывает на значительную позитивную динамику процессов интоксикации и позволяет рассматривать его в качестве важного звена в системе мероприятий, направленных на лечение и профилактику данного профессионального заболевания легких.

\section{Ключевые слова: пневмокониоз, хроническое обструктивное заболевание легких, работники, интоксикация.}

5. Calverley P., Viles B. New Pharmacotherapeutic Approaches for Chronic Obstructive Pulmonary Disease. Sermin. Respir. Crit. Care. Med. 2015. № 36 (4). P. 523-542.

6. Page C. M., Cazzola M. Bifunctional drugs for the treatment of astma and chronic obstructive pulmonary disease. Eur. Respir. J. 2014. Vol. 44 (2). P. 475-482.

7. Heulens N., Korf H., Janssen $\mathrm{W}$. Innate immune modulation in chronic obstructive pulmonary disease moving closer toward vitamin D therapy. $J$. Pharmacol. Exp. Ther. 2015. Vol. 353 (2). P. 360-368.

8. Jin Zh., Pan X., Zhou K. et al. Biological effects and mechanisms of action of mesenchymal stem cell therapy in chronic obstructive pulmonary disease. J. Int. Med. Res. 2015. Vol. 43 (3). P. 303-310.

9. Гайнитдинова В.В., Шарафутдинова Л.А., Камалтдинов И.М., Авдеев С.Н. Исследование структурно-функциональных особенностей нейтрофилов у больных хронической обструктивной болезнью легких с легочной гипертензией методом атомно-силовой микроскопии Пульмонология. 2014. № 4. C. 49-55.

10. Зубань А.Б., Островський М.М. Динаміка рівнів ендогенної інтоксикації та активності системи сурфактанта легень у процесі комплексного лікування хворих на хронічне обструктивне захворювання легень з включенням препарату тіотропія броміду. Медичні перспективи. 2017. Т. XXII. № 3, ч. 1. C. 95-100.

\section{BNuाrovment \& IIEMri! № 12021}


11. Рубцов Р.В.

Лейкоцитарні індекси як критерії інтоксикації у працівників гірничорудної та металургійної промисловості, хворих на пневмоконіоз у поєднанні з хронічним обструктивним захворюванням легень. Одеський медичний журнал. 2019. № 1. С. 50-55.

12. Про затвердження та впровадження медико-технологічних документів зі стандартизації медичної допомоги при хронічному обструктивному захворюванні легень : Наказ МО3 України від 27.06.2013 р. № 555. К., 2013. 146 с. URL: http://document.ua/prozatverdzhennja-tavprovadzhennja-medikotehnologichnih-ddoc 166218.html.

13. Global Initiative for Chronic Obstructive Lung Disease (GOLD). Pocket guide to COPD diagnosis, management and prevention 2019. URL : https://goldcopd.org. (Last accessed 02.03.2019). REFERENCES

1. Shpagina L.A., Poteryayeva E.L., Kotova O.S., Shpagin I.S. and Smirnova E.L. Aktualnyye problemy pulmonologii v sovremennoy profpatologicheskoy praktike [Actual Problems of Pulmonology in Modern Occupational Pathological Practice]. Occupational Medicine and Industrial Ecology. 2015 ; 9 : 11-14 (in Russian).

2. Elesevich S.A. and Razumov V.V. O patogeneticheskom edinstve pnevmokoniozov i pylevogo bronkhita [On Pathogenetic Unity of Pneumoconiosis and Dust Bronchitis]. Occupational Medicine and Industrial Ecology. 2007 ; 7 : 28-33 (in Russian).

3. Krasniuk O.P., Tkach S.I., Prylypska N.I., Shkondin A.M., Kovalchuk T.A. and Valutsyna V.M. Zastosuvannia klasyfikatsii pnevmokonioziv v Ukraini: metodychni rekomendatsii [Application of Pneumoconiosis Classification in Ukraine: Methodical
Recommendations]. Kyiv ; 2002. : 15 p. (in Ukrainian).

4. Loh Ch.H., Donohue J.E. and Ohar J.A. Review of Drung Safety and Efficacy of Arformoterol in Chronic Obstructive Pulmonary Disease. Expert. Opin. Drug Saf. 2015 ; 14 (3) :463-472.

5. Calverley P. and Viles B.

New Pharmacotherapeutic Approaches for Chronic Obstructive Pulmonary Disease. Sermin. Respir. Crit. Care. Med. 2015 ; 36 (4) : 523-542.

6. Page Ch.M. and

Cazzola M. Bifunctional Drugs for the Treatment of Astma and Chronic Obstructive Pulmonary Disease. Eur. Respir. J. 2014 ; 44 (2) : 475-482.

7. Heulens N., Korf H. and Janssen W. Innate Immune Modulation in Chronic Obstructive Pulmonary Disease Moving Closer Toward Vitamin D Therapy.

J. Pharmacol. Exp. Ther. 2015 ; 353 (2) : 360-368.

8. Jin Z., Pan V., Zhou K. et al. Biological Effects and Mechanisms of Action of Mesenchymal Stem Cell Therapy in Chronic Obstructive Pulmonary Disease.

J. Int. Med. Res. 2015 ; 43 (3) : 303-310.

9. Gaynitdinova V.V., Sharafutdinova L.A., Kamaltdinov I.M. and Avdeyev S.N. Issledovaniye strukturno-funktsionalnykh osobennostey neytrofilov $u$ bolnykh khronicheskoy obstruktivnoy boleznyu legkikh s legochnoy gipertenziyey metodom atomno-silovoy mikroskopii [Examination of the Structural and Functional Characteristics of Neutrophils by Patients with Chronic Obstructive Pulmonary Diseases with Pulmonary Hypertension by Atomic Force Microscopy]. Pulmonology. 2014 ; 4 : 49-55 (in Russian).

10. Zuban A.B. and

Ostrovskyi M.M. Dynamika rivniv endohennoi intoksykatsii ta aktyvnosti systemy surfaktanta lehen u protsesi kompleksnoho likuvannia khvorykh na khronichne obstruktyvne zakhvoriuvannia lehen iz vkliuchenniam preparatu tiotropiiu bromidu [Dynamics of Levels of Endogenous Intoxication and Activity of the Pulmonary Surfactant System in the Process of Complex Treatment of Patients with Chronic Obstructive Pulmonary Disease with the Inclusion of the Drug Tiotropium Bromide]. Medychni Perspektyvy. 2017; XXII (3) ;1: 95-100.

(in Ukrainian).

11. Rubtsov R.V.

Leikotsytarni indeksy yak kryterii intoksykatsii u pratsivnykiv hirnychorudnoi ta metalurhiinoi promyslovosti, khvorykh na pnevmokonioz u poiednanni z khronichnym obstruktyvnym zakhvoriuvanniam lehen [Leukocyte Indices as a Criterion for Intoxication by Workers of Mining and Metallurgical Industry, Patients with Pneumoconiosis in Combination with Chronic Obstructive Pulmonary Disease]. Odesa Medical Journal. 2019 ; 1 : 50-55 (in Ukrainian).

12. Pro zatverdzhennia ta vprovadzhennia medykotekhnolohichnykh dokumentiv zi standartyzatsii medychnoi dopomohy pry khronichnomu obstruktyvnomu zakhvoriuvanni lehen : Nakaz MOZ Ukrainy vid 27.06.2013 № 555

[On Approval and Implementation of Medical and Technological Documents for Standardization of Medical Care for Chronic Obstructive Pulmonary Disease : Order of the Ministry of Healthcare of Ukraine dd. June 27, 2013 № 555]. Kyiv; 2013 : 146 p. URL: http://document.ua/prozatverdzhennja-tavprovadzhennja medikotehnologichnih-ddoc 166218.html (in Ukrainian).

13. Global Initiative for Chronic Obstructive Lung Disease (GOLD). Pocket Guide to COPD Diagnosis, Management and Prevention. 2019. URL : https://goldcopd.org. (Last accessed 02.03.2019).

Надійшло до редакції 18. 10.2020 